\title{
Función mentalizcante de los cuentos de hadas
}

(Salamanca no obida a Bzimno Betteheim)

"Los cuentos de hadas responden a las eternas preguntas: ¿Cómo es el mundo en realidad? ¿Cómo tengo que vivir mi vida en él?

¿Cómo puedo ser realmente yo? Las respuestas pueden contener soluciones pero estas nunca son explícitas.

Los cuentos dejan que el niño imagine cómo puede aplicar a sí mismo lo que la historia le revela sobre la vida y la naturaleza humana. El cuento avanza de manera similar a cómo el niño ve y experimenta el mundo (...) el cuento le conforta mucho más que los esfuerzos por consolarlo basados en razonamientos y opiniones adultos" $\left(^{*}\right)$

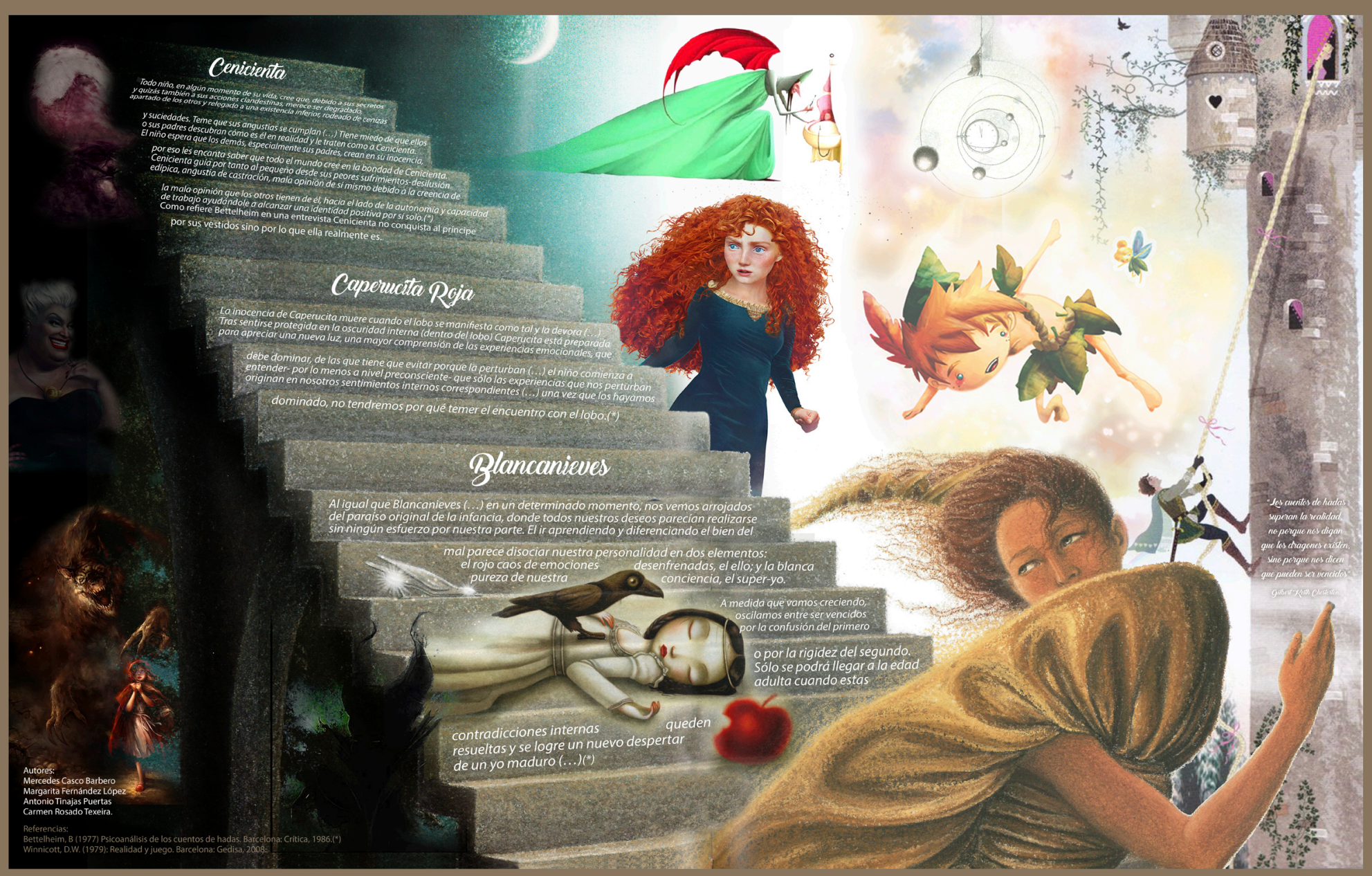


IV JORNADAS DE PSICOANÁLISIS RELACIONAL.

MENTALIZACIÓN. Salamanca, Octubre 2016

Autores: Mercedes Casco Barbero, Margarita Fernández López, Antonio Tinajas Puertas, Carmen Rosado Texeira.

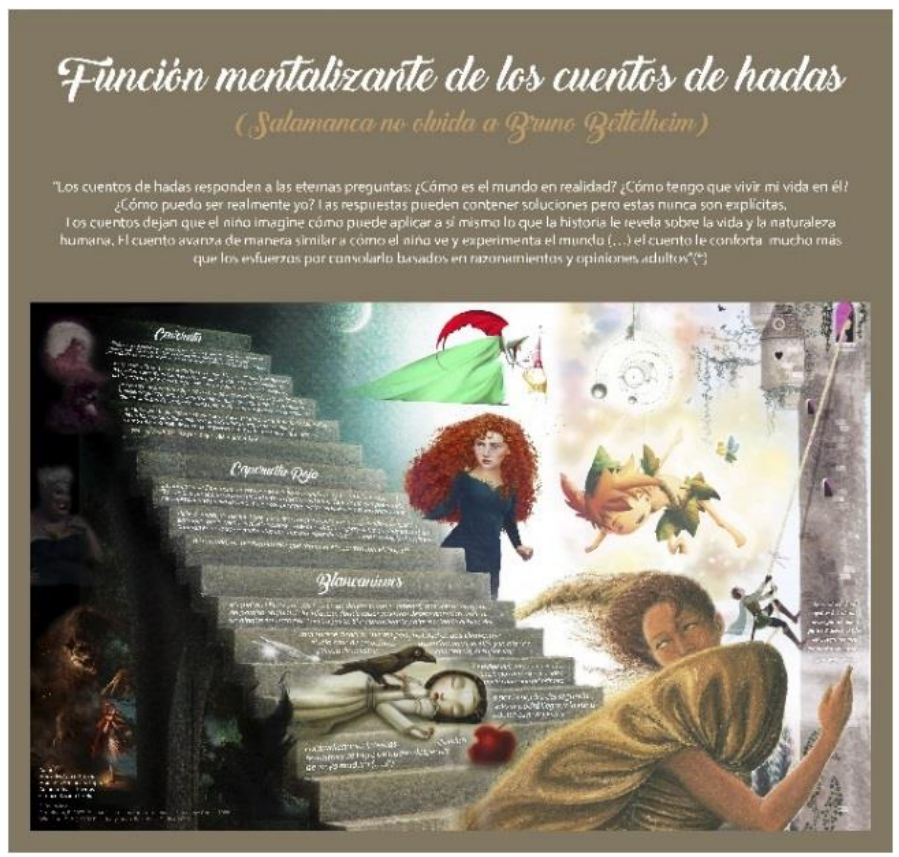

La idea que queremos transmitir con este póster es cómo los cuentos de hadas pueden servir a los niños de vehículo para mentalizar afectos y emociones. A través de una voz que entone sus emociones y de las historias de los personajes que en los cuentos aparecen pueden ir dotando de sentido a todo su mundo interno, imaginario, fantasmático.

Podríamos decir que es una forma de comunicación o “lenguaje común” que ayuda al niño a internalizar todas aquellas fantasías que en un momento pueden asustarle, confundirle... configurando así su estructura mental. 